\title{
Fluktuasi Schistosomiasis di Daerah Endemis Provinsi Sulawesi Tengah Tahun 2011-2018
}

\author{
THE SCHISTOSOMIASIS FLUCTUATION IN ENDEMIC AREAS CENTRAL \\ SULAWESI PROVINCE IN $2011-2018$
}

\author{
Anis Nurwidayati ${ }^{1 *}$, Phetisya Pamela Frederika Sumolang ${ }^{1}$, dan Mohammad Sudomo ${ }^{2}$ \\ ${ }^{1}$ Balai Penelitian dan Pengembangan Kesehatan Donggala \\ Jl. Masitudju no 58 Labuan Panimba, Labuan, Donggala, Sulawesi Tengah \\ ${ }^{2}$ Badan Penelitian dan Pengembangan Kesehatan \\ Jl. Percetakan Negara No 29, Jakarta Pusat 10560 \\ *Email : anisnurw21@gmail.com
}

Submitted : 29-01-2019, Revised : 15-05-2019, Revised : 16-05-2019, Accepted : 31-08-2019

\begin{abstract}
Schistosomiasis is one of the most important parasitic diseases in public health. Schistosomiasis infected 230 million people in 77 countries and 600 million people are at risk. Schistosomiasis in Indonesia is caused by a trematode (blood fluke) Schistosoma japonicum. The intermediate host is an amphibious snail, Oncomelania hupensis lindoensis. The disease occured only in Central Sulawesi, i.e in Napu and Bada Highlands, Poso District, and in Lindu Highland, Sigi District.Control activities have been implemented in the last 20 years. This paper aimed to describe the fluctuations of schistosomiasis infection rate among human in 2011-2018, snails, and rat in 2011-2017 in three endemic areas based on secondary data from the Central Sulawesi Provincial Health Office. The results showed that schistosomiasis infection rate among human fluctuated from year 2011-2018, as well as in snail and rat in 2011-2017, and there was a trend of increasing prevalence. The control efforts undertaken include surveying the feces of the population, detection of cercariae in snails and rat examination. It also carried out treatment of the population with praziquantel and eradication of the snail mechanically, chemically and biologically. Cross sectional activities to control schistosomiasis have also been conducted but still need to be strengthen to achieve schistosomiasis elimination in 2020.
\end{abstract}

Keywords: Schistosomiasis, prevalence, Schistosoma japonicum, Indonesia

\begin{abstract}
Abstrak
Schistosomiasis merupakan salah satu penyakit parasit terpenting dalam kesehatan masyarakat. Schistosomiasis telah menginfeksi 230 juta orang di 77 negara dan 600 juta orang berisiko terinfeksi. Schistosomiasis di Indonesia disebabkan oleh cacing trematoda jenis Schistosoma japonicum dengan hospes perantara keong Oncomelania hupensis lindoensis. Penyakit ini hanya ditemukan di Provinsi Sulawesi Tengah yaitu di Dataran Tinggi Napu dan Dataran Tinggi Bada, Kabupaten Poso serta Dataran Tinggi Lindu, Kabupaten Sigi. Berbagai upaya pengendalian sudah dilakukan selama lebih dari 20 tahun terakhir. Tulisan ini bertujuan untuk memaparkan fluktuasi kasus schistosomiasis pada manusia tahun 2011-2018, data schistosomiasis pada keong dan tikus tahun 2011-2017 di tiga daerah endemis tersebut dengan menganalisis data sekunder dari Dinas Kesehatan Provinsi Sulawesi Tengah. Hasil survei menunjukkan bahwa schistosomiasis masih berfluktuasi dari tahun 2011-2018 pada manusia, pada keong dan tikus tahun 2011-2017, serta terlihat adanya kecenderungan kenaikan prevalensi. Upaya pengendalian yang dilakukan meliputi survei tinja penduduk, deteksi serkaria pada keong dan pemeriksaan tikus. Selain itu juga dilakukan pengobatan penduduk dengan praziquantel dan pemberantasan keong secara mekanik, kimia dan biologi. Pengendalian terpadu oleh lintas sektor juga sudah dilaksanakan, akan tetapi masih perlu penguatan kembali peran lintas sektor untuk dapat mencapai target eliminasi schistosomiasis tahun 2020.
\end{abstract}

Kata kunci: Schistosomiasis, prevalensi, Schistosoma japonicum 


\section{PENDAHULUAN}

Schistosomiasis merupakan salah satu penyakit parasit terpenting dalam kesehatan masyarakat. Penyakit ini menimbulkan dampak kerugian ekonomi dan masalah kesehatan masyarakat di banyak negara berkembang. Schistosomiasis yang disebabkan oleh cacing Schistosoma japonicum ditemukan tersebar di negara-negara Asia, yaitu China, Jepang, Philipina, Indonesia, Vietnam, Laos, Thailand, Kamboja. Laporan WHO tahun 2010 menyebutkan, schistosomiasis telah menginfeksi 230 juta orang di 77 negara dan 600 juta orang berisiko terinfeksi oleh beberapa jenis cacing Schistosoma. ${ }^{1}$ Schistosomiasis di Indonesia disebabkan oleh cacing trematoda jenis S.japonicum dengan hospes perantara keong O.hupensis lindoensis. Penularan terjadi melalui kulit yaitu serkaria cacing S.japonicum menginfeksi hospes mamalia melalui kulit. Penyakit ini hanya ditemukan di Provinsi Sulawesi Tengah yaitu Dataran Tinggi Napu dan Dataran Tinggi Bada, Kabupaten Poso serta Dataran Tinggi Lindu, Kabupaten Sigi. ${ }^{2}$

Hospes perantara schistosomiasis di Indonesia adalah keong O.h.lindoensis yang bersifat amfibius. Keong perantara ini hidup tersebar luas di daerah endemis tetapi tidak merata, terbatas pada tempat - tempat tertentu yang disebut daerah fokus. Hospes definitif schistosomiasis adalah manusia dan hewan mamalia. Terdapat 13 mamalia yang diketahui terinfeksi oleh schistosomiasis antara lain : sapi (Bos sundaicus), kerbau (Bubalus bubalis), kuda (Equus cabalus), anjing (Canis familiaris), babi (Suis sp), musang (Vivera tangalunga), rusa (Cervus timorensis), berbagai jenis tikus (Rattus exulans, $R$. marmosurus, $R$. norvegicus, $R$. palellae). ${ }^{3,4}$

Schistosomiasis masih menjadi masalah kesehatan di daerah endemis meskipun berbagai program pengendalian telah dilaksanakan oleh tim terpadu pengendalian schistosomiasis. Tujuan penulisan untuk memaparkan fluktuasi atau kecenderungan kasus schistosomiasis pada manusia, keong dan hewan mamalia (tikus) pada tahun 2011-2018. Tulisan ini diharapkan dapat menjadi informasi bagi berbagai lintas sektor terkait program pengendalian schistosomiasis di Sulawesi Tengah, sehingga dapat mencapai target eliminasi schistosomiasis pada tahun 2020, dengan tingkat infeksi schistosomiasis di bawah $1 \%$.

\section{BAHAN DAN METODE}

Data yang disampaikan dalam tulisan ini merupakan data sekunder dari kegiatan survei rutin yang dilaksanakan oleh Dinas Kesehatan Provpinsi Sulawesi Tengah tahun 2011-2018. Data yang diambil adalah data hasil survei tinja penduduk, keong dan tikus yang dilaksanakan di daerah endemis schistosomiasis Napu, Lindu, dan Bada.

Survei tinja dilakukan pada penduduk di atas dua tahun di daerah endemis Napu, Lindu, Bada. Kegiatan pengumpulan tinja dilakukan dengan cara sebagai berikut: setiap orang dibagikan tiga pot tinja. Setiap pot diisi tinja dari satu kali BAB, sehingga tiga pot tinja diisi untuk tiga hari BAB. Setiap sampel dibuat tiga sediaan pemeriksaan menggunakan metode Kato-Katz. Pembuatan sediaan tinja untuk pemeriksaan dengan metode Kato-Katz adalah sebagai berikut: tinja diambil dengan lidi sebesar ibu jari, disaring dengan kawat kasa, tinja tersaring diambil untuk dibuat sediaan pada gelas benda dengan bantuan karton yang telah dilubangi (karton Kato) sebagai penentu volume tinja, ditutup dengan cellophan tape yang telah direndam dalam pewarna malachite-green glyserin, sediaan diratakan, diletakkan terbalik di atas kertas tisu agar cairan pewarna yang berlebihan dapat terserap, sediaan diperiksa di bawah mikroskop. ${ }^{5}$

Survei keong perantara schistosomiasis (O. hupensis lindoensis) dan tikus juga dilakukan bersamaan dengan pelaksanaan survei tinja penduduk. Survei keong dilakukan di daerah fokus keong dengan metode ring (ring method) atau metode koleksi bebas, tergantung dari kondisi fokus. Keong yang terkumpul kemudian dibawa ke laboratorium untuk pemeriksaan serkaria dan penentuan infection rate pada keong. Penentuan infection rate pada keong dilakukan dengan cara crushing keong O.hupensis lindoensis. Keong yang terkumpul diletakkan di atas gelas benda sebanyak tiga keong. Keong selanjutnya dipecah dengan pinset, selanjutnya ditetesi air. Keong yang sudah dipecah di atas gelas benda diperiksa di bawah mikroskop dengan perbesaran $10 \mathrm{x}$, untuk melihat serkaria S.japonicum. Infection rate pada keong dihitung dengan cara sebagai berikut ${ }^{5}$ : 
Jumlah keong positif serkaria x 100\% Jumlah total keong yang diperiksa

Survei tikus dilakukan karena tikus merupakan hewan sentinel sebagai petunjuk keberadaan daerah fokus keong. Survei tikus dilakukan dengan perangkap mati dengan umpan seperti singkong, kelapa atau ikan kering. Perangkap diletakkan di daerah yang dicurigai dilewati tikus atau terdapat sumber makanan tikus. Tikus yang tertangkap dibawa ke laboratorium untuk diperiksa lebih lanjut. Tikus ditimbang, diukur panjang total, panjang ekor, panjang telinga, panjang telapak kaki untuk penentuan jenis tikus. Selajutnya tikus dibedah, diperiksa dengan hati hati bagian vena porta hepatika, vena mesenterika untuk menemukan cacing S.japonicum. diambil sedikit jaringan hati tikus, digerus di atas gelas benda, kemudian dilihat di bawah mikroskop untuk menemukan telur cacing S.japonicum. ${ }^{5}$

\section{HASIL}

Fluktuasi prevalensi schistosomiasis di Provinsi Sulawesi Tengah tahun 2011-2018 dapat dilihat pada Gambar 1 atau Tabel 1.

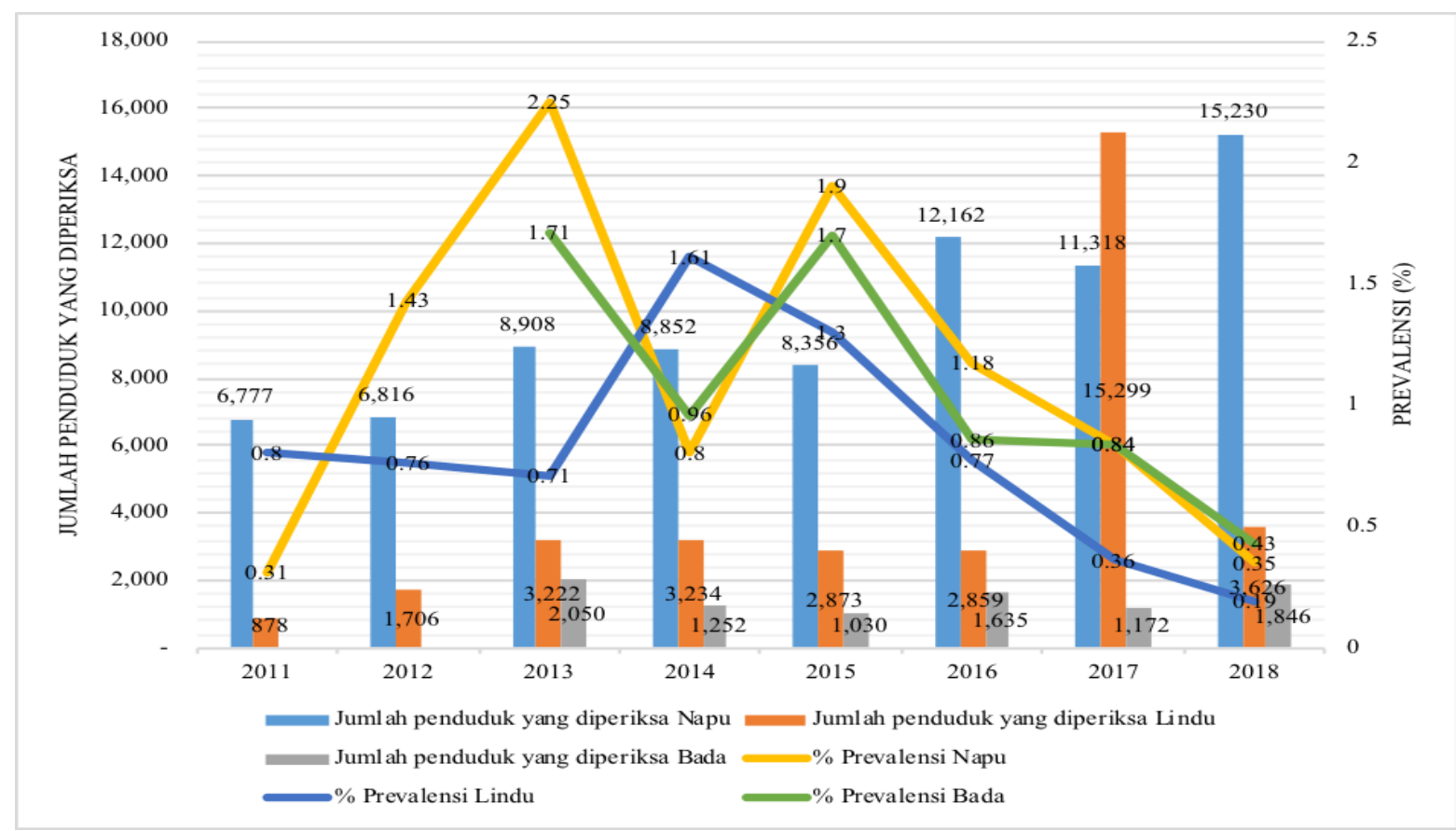

Gambar 1.Fluktuasi prevalensi schistosomiasis di Provinsi Sulawesi Tengah Tahun 2011-2018 (sumber: Dinas Kesehatan Provinsi Sulawesi Tengah, 2011-2018)

Tabel 1. Jumlah Penduduk Yang Diperiksa dan Prevalensi Schistosomiasis di Daerah Napu, Lindu, dan Bada Tahun 2011-2018

\begin{tabular}{|c|c|c|c|c|c|c|c|c|}
\hline \multirow[b]{2}{*}{ Tahun } & \multicolumn{3}{|c|}{ Napu } & \multicolumn{3}{|c|}{ Lindu } & \multicolumn{2}{|r|}{ Bada } \\
\hline & $\begin{array}{c}\text { Penduduk } \\
\text { yang } \\
\text { diperiksa }\end{array}$ & $\begin{array}{l}\text { Jumlah positif } \\
\text { schistosomiasis }\end{array}$ & $\begin{array}{l}\text { Prevalensi } \\
\text { (\%) }\end{array}$ & $\begin{array}{c}\text { Penduduk } \\
\text { yang } \\
\text { diperiksa }\end{array}$ & $\begin{array}{l}\text { Jumlah positif } \\
\text { schistosomiasis }\end{array}$ & $\begin{array}{l}\text { Prevalensi } \\
\text { (\%) }\end{array}$ & $\begin{array}{c}\text { Penduduk } \\
\text { yang } \\
\text { diperiksa }\end{array}$ & $\begin{array}{l}\text { Jumlah positif } \\
\text { schistosomiasis }\end{array}$ \\
\hline 2011 & 6.777 & 21 & 0,31 & 878 & 7 & 0,8 & & \\
\hline 2012 & 6.816 & 97 & 1,43 & 1.706 & 13 & 0,76 & & \\
\hline 2013 & 8.908 & 200 & 2,25 & 3.222 & 23 & 0,71 & 2.050 & 35 \\
\hline 2014 & 8.852 & 71 & 0,8 & 3.234 & 52 & 1,61 & 1.252 & 12 \\
\hline 2015 & 8.356 & 159 & 1,9 & 2.873 & 37 & 1,3 & 1.030 & 18 \\
\hline 2016 & 12.162 & 143 & 1,18 & 2.859 & 22 & 0,77 & 1.635 & 14 \\
\hline 2017 & 11.318 & 95 & 0,84 & 15.299 & 55 & 0,36 & 1.172 & 10 \\
\hline 2018 & 15.230 & 53 & 0,35 & 3.626 & 7 & 0,19 & 1.846 & 8 \\
\hline
\end{tabular}

Keterangan: Sumber data Dinas Kesehatan Provinsi Sulawesi Tengah 
Tabel 2. Angka Infeksi (\%) Serkaria Pada Keong O.hupensis lindoensis di Daerah Napu, Lindu, dan Bada Tahun 2011-2017

\begin{tabular}{|c|c|c|c|c|c|c|c|c|c|}
\hline \multirow[b]{2}{*}{ Tahun } & \multicolumn{3}{|c|}{ Napu } & \multicolumn{3}{|c|}{ Lindu } & \multicolumn{3}{|c|}{ Bada } \\
\hline & $\begin{array}{c}\text { Jumlah } \\
\text { keong } \\
\text { diperiksa }\end{array}$ & $\begin{array}{c}\text { Jumlah } \\
\text { keong } \\
\text { positif } \\
\text { serkaria }\end{array}$ & $\begin{array}{c}\text { Angka } \\
\text { infeksi } \\
(\%)\end{array}$ & $\begin{array}{c}\text { Jumlah } \\
\text { keong } \\
\text { diperiksa }\end{array}$ & $\begin{array}{c}\text { Jumlah } \\
\text { keong positif } \\
\text { serkaria }\end{array}$ & $\begin{array}{c}\text { Angka } \\
\text { infeksi } \\
(\%)\end{array}$ & $\begin{array}{c}\text { Jumlah } \\
\text { keong } \\
\text { diperiksa }\end{array}$ & $\begin{array}{c}\text { Jumlah } \\
\text { keong } \\
\text { positif } \\
\text { serkaria }\end{array}$ & $\begin{array}{c}\text { Angka } \\
\text { infeksi } \\
(\%)\end{array}$ \\
\hline 2011 & - & - & 0,98 & 646 & 23 & 3,56 & - & - & - \\
\hline 2012 & 2003 & 22 & 1,10 & 489 & 9 & 1,84 & - & - & - \\
\hline 2013 & 1792 & 22 & 1,23 & 620 & 7 & 1,13 & 555 & 15 & 2,7 \\
\hline 2014 & - & - & - & - & - & - & - & - & - \\
\hline 2015 & 1541 & 20 & 1,30 & 442 & 5 & 1,13 & 419 & 15 & 3,58 \\
\hline 2016 & - & - & - & 282 & 14 & 4,96 & 291 & 17 & 5,84 \\
\hline 2017 & 485 & 37 & 7,63 & 699 & 24 & 3,43 & 124 & 1 & 0,81 \\
\hline
\end{tabular}

Keterangan: Sumber data Dinas Kesehatan Provinsi Sulawesi Tengah; - : tidak tersedia data

Tabel 3. Angka Infeksi (\%) Schistosomiasis Pada Tikus di Provinsi Sulawesi Tengah Tahun 20112017

\begin{tabular}{|c|c|c|c|c|c|c|c|c|c|}
\hline \multirow[b]{2}{*}{ Tahun } & \multicolumn{3}{|c|}{ Napu } & \multicolumn{3}{|c|}{ Lindu } & \multicolumn{3}{|c|}{ Bada } \\
\hline & $\begin{array}{c}\text { Jumlah } \\
\text { tikus } \\
\text { diperiksa }\end{array}$ & $\begin{array}{c}\text { Jumlah tikus } \\
\text { positif cacing } \\
\text { S.japonicum }\end{array}$ & $\begin{array}{c}\text { Angka } \\
\text { infeksi } \\
(\%)\end{array}$ & $\begin{array}{c}\text { Jumlah } \\
\text { tikus } \\
\text { diperiksa }\end{array}$ & $\begin{array}{c}\text { Jumlah tikus } \\
\text { positif cacing } \\
\text { S.japonicum }\end{array}$ & $\begin{array}{c}\text { Angka } \\
\text { infeksi } \\
(\%)\end{array}$ & $\begin{array}{c}\text { Jumlah } \\
\text { tikus } \\
\text { diperiksa }\end{array}$ & $\begin{array}{c}\text { Jumlah tikus } \\
\text { positif cacing } \\
\text { S.japonicum }\end{array}$ & $\begin{array}{c}\text { Angka } \\
\text { infeksi } \\
(\%)\end{array}$ \\
\hline 2011 & - & - & 6,8 & - & - & - & - & - & - \\
\hline 2012 & 96 & 7 & 7,29 & 45 & 7 & 15,56 & - & - & - \\
\hline 2013 & 28 & 2 & 7,14 & 65 & 5 & 7,69 & 18 & 1 & 5,56 \\
\hline 2014 & - & - & - & - & - & - & - & - & - \\
\hline 2015 & 26 & 2 & 7,69 & 49 & 4 & 8,16 & 8 & 1 & 12,50 \\
\hline 2016 & - & - & - & 17 & 2 & 11,76 & 4 & 3 & 75 \\
\hline 2017 & 26 & 2 & 7,69 & 35 & 5 & 14,29 & 2 & 1 & 50 \\
\hline
\end{tabular}

Keterangan: Sumber data: Dinas Kesehatan Provinsi Sulawesi Tengah; - : tidak tersedia data

Berdasarkan Gambar 1/Tabel 1. terlihat bahwa prevalensi schistosomiasis pada manusia pada tahun 2011-2018 di daerah endemis Napu, Lindu, Bada berfluktuasi setiap tahunnya. Fluktuasi schistosomiasis pada manusia di Napu cenderung naik dari tahun 2011-2013, kemudian turun di tahun 2014. Kenaikan prevalensi schistosomiasis pada manusia ditemukan pada tahun 2015 di tiga daerah endemis, dan kemudian menurun pada tahun 2016 sampai dengan 2018.

Angka infeksi / infection rate schistosoma pada keong dapat dilihat pada Tabel 2. Data angka infeksi yang tersedia hanya sampai tahun 2017. Angka infeksi pada keong O.h.lindoensis pada tahun 2011-2013 terlihat sedikit mengalami kenaikan, akan tetapi tidak tersedia data di Napu tahun 2014 karena tidak dilakukan survei keong. Angka infeksi serkaria pada keong tahun 2015 terlihat hampir sama dengan tahun 2013. Tahun
2016 juga tidak tersedia data angka infeksi serkaria di Napu, dan tahun 2017 ditemukan kenaikan dari tahun 2015.

Angka infeksi serkaria pada keong di Lindu pada tahun 2011 sampai 2013 ditemukan menurun, akan tetapi tidak tersedia data angka infeksi pada keong di tiga daerah endemis karena pada tahun tersebut tidak dilakukan survei pada keong. Angka infeksi serkaria pada keong di Lindu tahun 2015 ditemukan sama dengan angka infeksi pada tahun 2013, kemudian terjadi kenaikan pada tahun 2016, dan turun kembali pada tahun 2017.

Data angka infeksi keong di Bada tahun 2011 dan 2012 tidak tersedia karena survei keong di Bada baru dilakukan mulai tahun 2013. Angka infeksi serkaria pada keong di Bada tahun 2015 ditemukan lebih tinggi dari tahun 2013, kemudian naik di tahun 2016, dan ditemukan menurun pada tahun 2017. 
Angka infeksi schistosomiasis pada tikus dapat dilihat pada Tabel 3. Angka infeksi schistosomiasis pada tikus pada tahun 2011-2017 terlihat relatif stabil, meskipun tidak tersedia data di Napu tahun 2014 dan 2016. Pada tahun 2011 tidak tersedia data angka infeksi schistosomiasis di daerah Lindu. Angka infeksi schistosomiasis di Lindu telihat terjadi penurunan pada tahun 2013, kemudian mulai meningkat sejak tahun 2015 sampai 2017. Pada tahun 2014 tidak tersedia data angka infeksi schistosomiasis pada tikus di tiga daerah endemis karena pada tahun tersebut tidak dilakukan survei pada tikus. Data angka infeksi tikus di Bada tahun 2011 dan 2012 tidak tersedia karena survei tikus di Bada baru dilakukan mulai tahun 2013. Jumlah tikus yang ditemukan positif di Bada sebenarnya relatif stabil, yaitu berkisar satu sampai tiga ekor tikus.

\section{PEMBAHASAN}

Prevalensi schistosomiasis pada manusia di Napu terlihat meningkat dari tahun 2011 sampai 2013. Prevalensi ditemukan turun pada tahun 2014, akan tetapi naik lagi pada tahun 2015, meskipun tahun 2016 sampai tahun 2018 ditemukan semakin menurun. Prevalensi schistosomiasis terlihat naik pada tahun 2015. Kenaikan tersebut dapat terjadi karena jumlah penduduk yang diperiksa lebih banyak dari tahun sebelumnya, sehingga dapat menjaring penderita schistosomiasis lebih banyak. Berdasarkan Gambar 1/Tabel 1 ditemukan pola yang berbeda dengan fluktuasi schistosomiasis di Lindu. Terjadi penurunan prevalensi di Lindu meski tidak terlalu besar dari tahun 20112013, dan justru terjadi kenaikan pada tahun 2014. Kenaikan dapat terjadi karena jumlah penduduk yang diperiksa lebih banyak dari tahun sebelumnya, sehingga dapat menjaring penderita schistosomiasis lebih banyak.

Pola yang sama dengan fluktuasi di Napu adalah ditemukan penurunan prevalensi schistosomiasis di Lindu dan Bada pada tahun 2015 sampai dengan 2018. Penurunan dapat terjadi karena program pengendalian schistosomiasis yang lebih intensif.

Kegiatan pengendalian schistosomiasis

yang dilakukan pada tahun 2014 adalah pengobatan pada manusia secara intensif, sehingga ditemukan penurunan prevalensi schistosomiasis pada tahun tersebut. Hal tersebut sejalan dengan penelitian di Afrika yang menunjukkan bahwa dengan pengobatan praziquantel yang intensif dapat menurunkan kasus schistosomiasis akibat S.mansoni setahun setelah pengobatan. ${ }^{6}$

Fluktuasi kasus terjadi karena banyaknya faktor dalam penularan schistosomiasis, di antaranya adalah adanya hospes perantara schistosomiasis yaitu keong O.hupensis lindoensis. Fluktuasi juga dapat terjadi karena schistosomiasis di Indonesia disebabkan oleh S.japonicum yang sifatnya zoonosis sejati. $^{3}$ Beberapa hewan mamalia seperti tikus, kerbau, babi, anjing, sapi dan sebagainya diketahui sebagai hospes reservoar S.japonicum di wilayah endemis Napu dan Lindu, Sulawesi Tengah. Keberadaan hewan tersebut menyebabkan siklus penularan schistosomiasis dapat terus berlangsung melalui siklus silvatik. ${ }^{3}$ Prevalensi schistosomiasis pada ternak di daerah endemis Lindu masih di atas $1 \%$. Penelitian pada tahun 2011 menunjukkan angka prevalensi schistosomiasis pada hewan mamalia di empat desa Lindu, cukup tinggi pada kerbau $(36,4-47,5 \%)$, sapi $(16,7-33 \%)$, dan babi $(8,3-$ 20\%). ${ }^{7}$ Infeksi S. japonicum pada tikus di Dataran Tinggi Napu Kabupaten Poso Sulawesi Tengah mencapai $22,7 \%(5 / 22)$ dengan jenis tikus yang tertangkap yaitu Rattus norvegicus dan $R$. exulans, dan infeksi tertinggi ditemukan pada jenis $R$. norvegicus. ${ }^{8}$ Dengan demikian pemberantasan schistosomiasis tidak dapat hanya pada sektor kesehatan manusia saja, melainkan juga sektor lingkungan meliputi mengurangi fokus keong perantara maupun penanganan hewan mamalia yang dapat menjadi reservoir.

Strategi WHO untuk pengendalian schistosomiasis berfokus pada pengurangan penyakit melalui pengobatan periodik pada kelompok target dengan praziquantel. Hal ini melibatkan pengobatan teratur semua orang pada kelompok berisiko. Tujuan pengobatan dalam pengendalian schistosomiasis adalah untuk mengurangi penyakit. Pengobatan secara periodik pada populasi yang berisiko dapat menyembuhkan gejala ringan dan mencegah berkembangnya penyakit menjadi parah pada manusia yang 
terinfeksi. ${ }^{1,10}$

Salah satu kegiatan pengendalian schistosomiasis yang telah dilakukan oleh Dinas Kesehatan Provinsi Sulawesi Tengah yaitu pengobatan massal apabila prevalensi di atas $1 \%$, dan pengobatan selektif jika prevalensi pada manusia kurang dari 1\%. Pengobatan schistosomiasis dilakukan dengan menggunakan praziquantel $(60 \mathrm{mg} / \mathrm{kg} \mathrm{BB})$, karena sangat efektif terhadap semua bentuk schistosomiasis, baik fase akut, kronik maupun yang sudah mengalami spleenomegali. Efek samping praziquantel ringan dan hanya diperlukan satu dosis yaitu $60 \mathrm{mg} / \mathrm{kg}$ BB yang dibagi dua dan diminum dalam tenggang waktu 4-6 jam. Hasil evaluasi pengobatan pada tahun 2011 menunjukkan bahwa praziquantel masih efektif, namun evaluasi obat masih perlu dilakukan mengingat interval waktu evaluasi sudah cukup lama. ${ }^{11}$

Salah satu upaya pengendalian schistosomiasis yang efektif adalah dengan pemutusan rantai penularan yaitu dengan pengendalian keong perantara schistosomiasis, O.h.lindoensis. ${ }^{12}$ Kegiatan pengendalian keong oleh Dinas Kesehatan Propinsi Sulawesi Tengah adalah dengan dua cara yaitu secara mekanik dan kimiawi. Pengendalian secara kimiawi dilakukan dengan penyemprotan moluskisida Bayluscide $70 \%$ WP dengan dosis $0,2 \mathrm{gr} / \mathrm{m}^{2}$ setiap 6 bulan sekali pada fokus aktif. Pengendalian secara mekanik dilakukan dengan berbagai cara misalnya perbaikan dan pembuatan saluran air, pembersihan saluran air, pengeringan daerah fokus, pemanfaatan lahan fokus menjadi lahan produktif. ${ }^{13}$

Penggunaan moluskisida sintetik seperti niclosamide memiliki kekurangan yaitu kecenderungan bersifat toksik terhadap lingkungan, ikan dan biota mikroskopis (zooplankton dan fitoplankton), serta mempengaruhi vegetasi di habitat keong perantara schistosomiasis. ${ }^{14}$ Kekurangan moluskisida sintetik mendorong perlunya penelitian tentang tanaman yang berpotensi sebagai penghasil moluskisida alternatif pengganti niklosamide. Penggunaan tanaman bermoluskisida diharapkan lebih sederhana, murah, dan lebih ramah lingkungan.

Berbagai tanaman yang memiliki kandungan moluskisida ditemukan dari anggota family Solanaceae, Phytolaccaceae, Fabaceae, Rubiaceae, dan Euphorbiaceae. Ekstrak tanaman dari jenis Phytolacca dodecandra (L' Herit) Balanites aegyptiaca, Sapindus saponaria, Swartzia madagascarensis, Jatropha curcas, dan Riccinus communis diketahui memiliki daya bunuh terhadap keong perantara schistosomiasis (Bulinus africanus, Biomphalaria glabrata, dan O.hupensis lindoensis). ${ }^{15-20}$

Sebuah penelitian meta analisis menunjukkan bahwa penyediaan air bersih yang bebas serkaria berperan penting dalam pemutusan siklus schistosomiasis. Mengurangi kontak dengan air yang terinfeksi juga sangat penting dalam pencegahan schistosomiasis. Keberadaan sarana sanitasi seperti jamban juga sangat penting dalam mencegah penularan schistosomiasis, karena apabila terdapat telur dalam tinja, maka tidak akan mencapai hospes perantara. Dengan demikian, perlu penyediaan jamban bagi masyarakat dan digunakan dengan baik sebagai salah satu upaya pencegahan schistosomiasis. ${ }^{21}$

Kebijakan pengendalian schistosomiasis memerlukan peran lintas sektor dan berbagai tokoh masyarakat dalam pengendalian schistosomiasis. Dalam hal peningkatan cakupan survei tinja dan pengisian sampel tinja sesuai prosedur diperlukan kerjasama antara laboratorium schistosomiasis dan puskesmas di daerah endemis, misalnya pasien yang berobat diwajibkan membawa sampel tinjanya untuk diperiksa schistosomiasis. Selain itu juga perlu pemanfaatan kader untuk membantu update data jumlah penduduk di daerah endemis.

Peran lintas sektor dalam pengendalian schistosomiasis sudah ditetapkan dengan SK Gubernur Sulawesi Tengah Nomor: 443.2/201/ DISKESDA - G.ST/ 2012 tentang Tim Terpadu Pengendalian Schistosomiasis Provinsi Sulawesi Tengah tahun 2012-2016. Tim terpadu pengendalian schistosomiasis tersebut terdiri dari Dinas Kesehatan, Balai Litbang P2B2 Donggala, Balitbang Daerah, Dinas Pertanian, Peternakan dan Kesehatan Hewan, Dinas Pekerjaan Umum, Dinas Kehutanan, Dinas Perkebunan, Dinas Pendidikan dan Pengajaran, PKK, Dinas Perikanan dan Kelautan, Bappeda, BPMPD, Badan Lingkungan Hidup, dan Balai Besar Taman 
Nasional Lore Lindu. ${ }^{13}$

Kegiatan pengendalian schistosomiasis yang telah dilaksanakan oleh tim terpadu dari berbagai lintas sektor antara lain survei tinja, pengobatan pada masyarakat, survei keong dan tikus, penyemprotan keong dengan moluskisida (Bayluscide), pengeringan daerah fokus, pemasangan tanda peringatan daerah fokus, alokasi anggaran kegiatan pengendalian, pemeriksaan hewan ternak, penanaman sejuta pohon, pembagian itik pada masyarakat, pembagian ikan pada masyarakat, pembuatan saluran air dan irigasi, peran serta dasa wisma, kegiatan penyuluhan. ${ }^{13}$

\section{KESIMPULAN}

Prevalensi schistosomiasis di daerah endemis Sulawesi Tengah tahun 2011-2018 masih berfluktuasi baik pada manusia, keong perantara, maupun tikus. Pengendalian oleh Tim Terpadu Pengendalian Schistosomiasis Provinsi Sulawesi Tengah berperan dalam penurunan schistosomiasis di daerah endemis.

\section{UCAPAN TERIMA KASIH}

Terimakasih disampaikan kepada Kepala Dinas Kesehatan Provinsi Sulawesi Tengah, Pemegang Program Pengendalian Schistosomiasis Bapak Abdul Rauf, SKM atas informasi data schistosomiasis di Sulawesi Tengah.

\section{DAFTAR RUJUKAN}

1. WHO. Schistosomiasis Fact Sheet. http:// www.who.int. Published 2013.

2. Hadidjaja P. Schistosomiasis Di Indonesia. 1st ed. Jakarta: UI Press; 1985.

3. Sudomo M. Penyakit Parasitik Yang Kurang Diperhatikan Di Indonesia. Orasi Pengukuhan Profr Ris Bid Entomol dan Moluska. Badan Litbang Kesehatan. Jakarta; 2008.

4. Sudomo M, Pretty MDS. Pemberantasan Schistosomiasis di Indonesia. Bul Penelit Kesehat. 2007;35 (1 Mar). http://ejournal. litbang.depkes.go.id/index.php/BPK/article/ view/2136. Accessed January 29, 2016.

5. Schistosomiasis. DJPPM (P2M) dan
PPPL (P2PL). Pedoman Pengendalian Schistosomiasis Di Indonesia. Jakarta: Ditjen PPM; 2015.

6. Assaré RK, Yao PK, Guessan NAN. Sustaining Control of Schistosomiasis Mansoni in Western Côte d' Ivoire : Results from a SCORE Study, One Year after Initial Praziquantel Administration. 2016;(Ci):1-17. doi:10.1371/journal.pntd.0004329.

7. Gunawan, Hayani Anastasia, Phetisya Pamela F.S R. Kontribusi Hewan Mamalia Sapi, Kerbau, Kuda, Babi dan Anjing dalam Penularan Schistosomiasis di Kecamatan Lindu Kabupaten Sigi Propinsi Sulawesi Tengah Tahun 2013. Media Litbangkes. 2014; 24( 4):209-214.

8. Nurjana MA. Infeksi Schistosoma japonicum Pada Hospes Reservoir Tikus di Dataran Tinggi Napu, Kabupaten Poso, Sulawesi Tengah Tahun 2012. 2013;23(3):137-142.

9. Adenowo AF, Oyinloye BE, Ogunyinka BI, Kappo AP. Impact of human schistosomiasis in sub-Saharan Africa. Braz J Infect Dis. 2015;19(2):196-205. doi:10.1016/j. bjid.2014.11.004.

10. Kaatano GM, Siza JE, Mwanga JR, et al. Integrated Schistosomiasis and SoilTransmitted Helminthiasis Control over Five Years on Kome Island, Tanzania. 2015;53(5):535-543.

11. Nurwidayati A, Garjito TA, Sumolang PPF, Risti R. Analisis Gen Penyandi Schistosoma japonicum Gluthation $s$ Transferase (SJ26GST) di Dataran Tinggi Lindu, Sulawesi Tengah, Indonesia. Bul Penelit Kesehat. 2014;42(4 Des):231-236. http://ejournal. litbang.depkes.go.id/index.php/BPK/article/ view/3661. Accessed January 27, 2016.

12. King CH, Bertsch D. Historical Perspective: Snail Control to Prevent Schistosomiasis. PLoS Negl Trop Dis. 2015;9(4):e0003657. doi:10.1371/journal.pntd.0003657.

13. Dinas Kesehatan Provinsi Sulawesi Tengah. Laporan Schistosomiasis Sulawesi Tengah (2011-2018). Palu : Dinas Kesehatan Provinsi Sulawesi Tengah; 2018.

14. Rug M, Ruppel A. Toxic activities of the plant Jatropha curcas against intermediate snail hosts and larvae of schistosomes. 1997.

15. Jianbin L. Study Of Plant Molluscicide From 
Jatropha curcas seed (JCS) In Laboratory. Hubei Institute Of Schistosomiasis Control. http//www.Intox.Org/databank/documents/ plant/jatropha/jcurc.htm. Published 2000.

16. Li C, Devappa RK, Liu J, Lv J, Makkar HPS, Becker K. Toxicity of Jatropha curcas phorbol esters in mice. Food Chem Toxicol. 2010;48(2):620-625. doi:10.1016/j. fct.2009.11.042.

17. John A O. Indigenous Plants and Schistosomiasis Control in South Africa: MolluscicidalActivity of Some Zulu Medicinal Plants. Boletín Latinoam y del Caribe Plantas Med y Aromáticas. 2004;3:8-22.

18. Nurwidayati A. The phytochemical screening and thin layer chromatography results of Jatropha gossypiifolia seeds. Heal Sci J Indones. 2012;3(2 Des):99-103. http:// ejournal.litbang.depkes.go.id/index.php/HSJI/ article/view/3075. Accessed March 24, 2016.
19. Anis Nurwidayati, Ni Nyoman Veridiana, Octaviani Y. Efektivitas Ekstrak Biji Jarak Merah (Jatropha gossypiifolia L), Jarak Pagar (J.curcas), dan Jarak Kastror (Riccinus communis) Famili Euphorbiaceae terhadap Hospes Perantara Schistosomiasis, Keong Oncomelania hupensis lindoensis. BALABA. 2014;10(1):9-14.

20. Widayati AN, Rosmini, Isnawati R, Kurniawan A, Srikandi Y, Risti. Pengujian Ekstrak Biji Jarak Merah(Jatropha Gossypiifolia L) Terhadap Keong Perantara Schistosomiasis, Oncomelania hupensis lindoensis di Napu, Kabupaten Poso, Sulawesi Tengah. J Vektora. 2016;8(1):13-22.

21. Grimes JE, Croll D, Harrison WE, Utzinger J, Freeman MC, Templeton MR. The roles of water, sanitation and hygiene in reducing schistosomiasis: a review. Parasit Vectors. 2015;8(1):156. doi:10.1186/s13071-0150766-9. 